Article

\title{
Carbon Lock-Out: Leading the Fossil Port of Rotterdam into Transition
}

\author{
Rick Bosman *, Derk Loorbach, Jan Rotmans and Roel van Raak
}

Dutch Research Institute for Transitions, Erasmus University Rotterdam, 3062 PA Rotterdam, The Netherlands; loorbach@drift.eur.nl (D.L.); rotmans@fsw.eur.nl (J.R.); vanraak@drift.eur.nl (R.v.R.)

* Correspondence: bosman@drift.eur.nl

Received: 16 May 2018; Accepted: 10 July 2018; Published: 20 July 2018

\begin{abstract}
The port of Rotterdam is a global leader in the fossil fuel economy, with a 50\% market share for fossil fuel products in North-Western Europe. Although it is one of the most efficient and innovative ports globally, over the last decade it has seen a gradual increase of pressures on its activities and the need to develop alternative low-carbon strategies. This paper describes how a turbulent energy context, growing societal pressure and a change in the leadership of the Port Authority opened up space for a transition management process. The process impacted the business strategy and the discourse amongst its leaders and contributed to the set-up of a transition unit and a change in investments. It subsequently led to an externally oriented transition arena process with incumbent actors in the port area and actors from outside around the transition pathway to a circular and bio-based economy. By exploring how transition management could support the repositioning of incumbent actors in the energy transition, the research contributes to discussions in the transitions literature on regime destabilisation, the role of (incumbent) actors in transitions, and large-scale energy-intensive industries as the next frontier in the energy transition.
\end{abstract}

Keywords: Port of Rotterdam; fossil fuels; regime destabilisation; transition management

\section{Introduction}

Global concerns over climate change, resources and global economic changes combined with technological disruptions and geopolitical tensions have brought the energy transition to the centre of global debate. After decades of debates around the need for and potential benefits of such an energy transition, the Paris Agreement [1] has now also secured political commitment to address climate change at the global level. Forecasting studies, however, show that the current pace of innovation and (policy) change is not sufficient to bring the 1.5 to 2 degrees warming target within reach, rather the world is on track for a 4-6 degrees warming by the end of this century [2].

It is clear beyond reasonable doubt now that the main causes of climate change are manmade greenhouse gas emissions, most prominently carbon dioxide from burning fossil fuels [3]. Recent research finds that if global warming is to remain well below $2{ }^{\circ} \mathrm{C}$ (and preferably 1.5 degrees) as has been agreed upon in Paris, $82 \%$ of the currently known coal, $50 \%$ of the gas, and $33 \%$ of the oil reserves cannot be burned unabated [4]. Thus, a shift towards renewable and sustainable energy sources and away from unsustainable fossil fuels is necessary. Since the use of fossil fuels is deeply embedded in modern lives and societies, such a shift away from fossil fuels requires tremendous societal change across a wide range of domains and activities.

The academic field of sustainability transitions deals with understanding such fundamental societal change processes. It is rooted in multiple disciplines, including innovation studies, evolutionary economics, institutional theory and complexity theory. A transition is conceptualised as a fundamental change in a regime, the dominant structure, culture and practices in a societal 
(sub)system that is the result of a co-evolution of economic, technological, institutional, cultural, and ecological developments at different scale levels. Such transitions often cut across a variety of domains and stakeholders and are thus long-term (25-50 years), highly complex and contested. Contemporary transitions are often related to sustainability goals in order to resolve a number of persistent problems confronting modern societies [5]. The growing societal efforts to move away from fossil fuels and resources towards renewable resources, as subsumed under the 'energy transition' [6], fit neatly to the conceptualisation of a sustainability transition as outlined above.

Transition management has been developed as a new mode of governance for sustainable development [7-9]. While transition research and transition management direct quite some attention towards experimentation and innovation in sustainable niches, to date there is little experience of how the decline or break down of existing practices, industries and regimes proceeds and whether transition management can be applied to support change-minded incumbents operating in the context of a destabilising regime. As such, our research question is: What is the role of incumbents in regime destabilization and how can they be supported using and adapting the transition management approach?

Our research is based on a transition management process in the Port of Rotterdam stretching out from early-2015 to mid-2017. The Port of Rotterdam is one of the largest fossil fuel hubs in the world: half of the total throughput is related to fossil fuel products, $21 \%$ of the refining capacity in the Hamburg-Le Havre range is located in the Port and it supplies 50\% of North-Western Europe's demand for fossil fuels [10]. It had been developing sustainability strategies for years, but increasing societal and economic pressures and a change in leadership of the Port Authority opened up space for a transition management process. At this time, mid-2015, the Paris Agreement had not yet been agreed upon and even though climate concerns and sustainability goals were discussed, the Port Authority did not have any strategy that included the potential phase-out of fossil fuels. The process was commissioned by and carried out in close engagement with the Port Authority, a semi-public organisation responsible for the Port.

Working intensively with and within the Port Authority allowed us to gain a deep understanding of how incumbent actors perceive transitional changes in their context and their role in anticipating this. It also offered an opportunity to develop and test strategies to help incumbent actors navigate such a highly challenging context. The described action research process applied and adapted transition management to this context. At the same time, the process helped to gain a deeper understanding of regime destabilisation, the role of (incumbent) actors in transitions and large-scale energy-intensive industries as the next frontier in the energy transition.

The article is structured as follows: In Section 2, we present the theoretical underpinnings of our research, building on recent insights in regime destabilisation, we introduce transition management and the adaptations we made to apply it in a destabilising regime context in close cooperation with an incumbent. In Section 3, we describe the transition management (TM) process including the considerations of applying TM in this context. In Section 4, we discuss the effects and implications to which the process contributed. In Section 5, we reflect on our findings and relate the insights and lessons learned to transitions literature.

\section{Regime Destabilisation, (Incumbent) Agency, and Transition Management}

A transition is defined as a radical, structural change of a societal (sub)system that is the result of the co-evolution of economic, cultural, technological, ecological, and institutional developments at different scale levels [7]. It comes about through the simultaneous build-up of sustainable alternatives and the breakdown of existing unsustainable practices [11]. A core concept in transition research is the regime. While it is defined in several ways [12-15], the different definitions have in common that regimes provide coordination and stability to societal systems that provide a particular societal function. We adopt the following regime definition: the dominant culture, structure, and practices within a societal system [16-18]. As a transition is a structural change of an existing regime into another, 
it thus implies destabilisation and (partial) reconfiguration of regimes. Such regime destabilization can be caused by external shocks, internal structural problems and bottom-up innovations in niches [5].

\subsection{Regime Destabilisation}

Based on an elaborate review of historical transition cases, Arranz [19] shows that different kinds of landscape pressures play a crucial role in regime destabilisation. Building on insights from industrial economics, evolutionary economics, neo-institutional theory, and management studies, and a historical case study of the decline of the British coal industry, Turnheim and Geels $[20,21]$ understand regime destabilisation as resulting from three mutually reinforcing processes:

1. building up of economic and socio-political pressures;

2. performance problems within the regime by undermining resource flows and legitimacy;

3. actors lose commitment to elements of the regime, in turn, exacerbating pressures and performance problems.

Karltorp and Sanden [22] show how diverging actor strategies in the face of transitional pressures can lead to regime fragmentation and destabilization. Bosman et al. [23,24] add to this understanding of destabilization and actors losing commitment to the regime from a discursive perspective, analysing how alternative 'storylines in the making' undermine the logic and coherence of the previously hegemonic incumbent discourse. Their work suggests that when incumbents' explanations no longer keep up with new developments, it impairs their legitimacy and provides thrust to alternative storylines supported by actors new or foreign to the incumbent regime.

To our knowledge, the first comprehensive venture towards informing destabilisation interventions is by Kivimaa and Kern [25]. According to them, the concept of regimes implies "rules, technologies and actor-networks as the main components that can enforce stability or, when they change, create instability of the regime". As such, they propose four regime destabilising functions that policymakers could enact for destabilisation directed at these components:

1. control policies

2. significant changes in regime rules

3. reduced support for dominant regime technologies

4. changes in social networks, replacement of key actors

From a transition governance perspective, however, it is not evident that policymakers will deliberately pursue regime destabilisation nor are they automatically in a position to pursue actions towards that end, especially when the government is on the receiving end or part of the incumbent regime (cf. Reference [26]). A key question is, therefore, what factors or interventions could help to create the context within which such policies or interventions can emerge or be implemented.

\subsection{Incumbents in Transition}

Recently, attention in the transition literature is shifting from a focus on systems and external shocks as drivers for transitions, towards one of developing an understanding of the way actors and their agency and power advances or impedes transitions (see e.g., References [27-31]. However, an ambiguous picture emerges: Smink et al. [32] found that incumbents tend to hamper change. Geels [14] even goes so far as to claim that 'regime stability is the outcome of active resistance by incumbent actors'. Vleuten and Hogselius, in their study of European liberalisation of energy markets, provide a different view by showing that incumbent actors can also drive change [33]. The work of Hengelaar [34], Hengelaar and Bosman [35], Bosman et al. [23], and Karltorp and Sanden [22] provide a more differentiated view showing that incumbent actors can respond differently to transitional pressures and that these diverging strategies might lead to misalignments in the regime. Turnheim and Geels $[20,21]$ propose that in regime destabilization, actors eventually lose their commitment to elements of the regime. Thus, although it stays implicit in their conceptualisation, Turnheim and 
Geels [20] introduced a dynamic view on the position of incumbents: initially their efforts are geared towards maintaining the status quo, while over time they may shift their attention and contribute to accelerating a transition.

\subsection{Transition Management in Context of a Destabilising Regime}

Transition management is a prescriptive and experimental governance approach focused on mobilising and connecting transformative agency to help guide and accelerate sustainability transitions. Transition management asserts that transitions cannot be controlled but aims to stimulate transitions by offering actors insight into transition dynamics, developing guiding and mobilising visions, transition agendas and experiments. It is based upon the following principles [36]:

- $\quad$ Long-term thinking (at least 25 years) in order to inform short-term action and policies.

- Creating space for niches with a focus on frontrunners to promote radical innovation.

- $\quad$ (Social) learning about different actor perspectives and a variety of options (requiring a wide playing field) as a necessary precondition for change.

- $\quad$ Selective participatory decision-making and interaction between stakeholders in order to develop support for policies and to engage actors in reframing problems and solutions through social learning.

An important framework is the Transition Management cycle, whose components are: 1 . structure the persistent problem in question and establish and organize the transition arena; 2 . develop a transition agenda, images of sustainability and derive the necessary transition paths; 3 . establish and carry out transition experiments and mobilize the resulting transition networks; 4 . monitor, evaluate and learn lessons from the transition experiments and, based on these, make adjustments in the vision, agenda and coalitions. A central instrument to implement transition management is the transition arena, a temporary innovation network consisting of a diverse set of frontrunners and change-minded regime players. In a sequence of several sessions, such an arena is 'used to develop new substance (ideas, agendas visions); to support a process (of network/coalition building, learning); and to subtly influence existing regimes' [36]. While the main process steps are prescribed in the transition arena methodology (see Figure 1), it leaves room for adaptation to the particular context in which it is applied $[8,36]$.
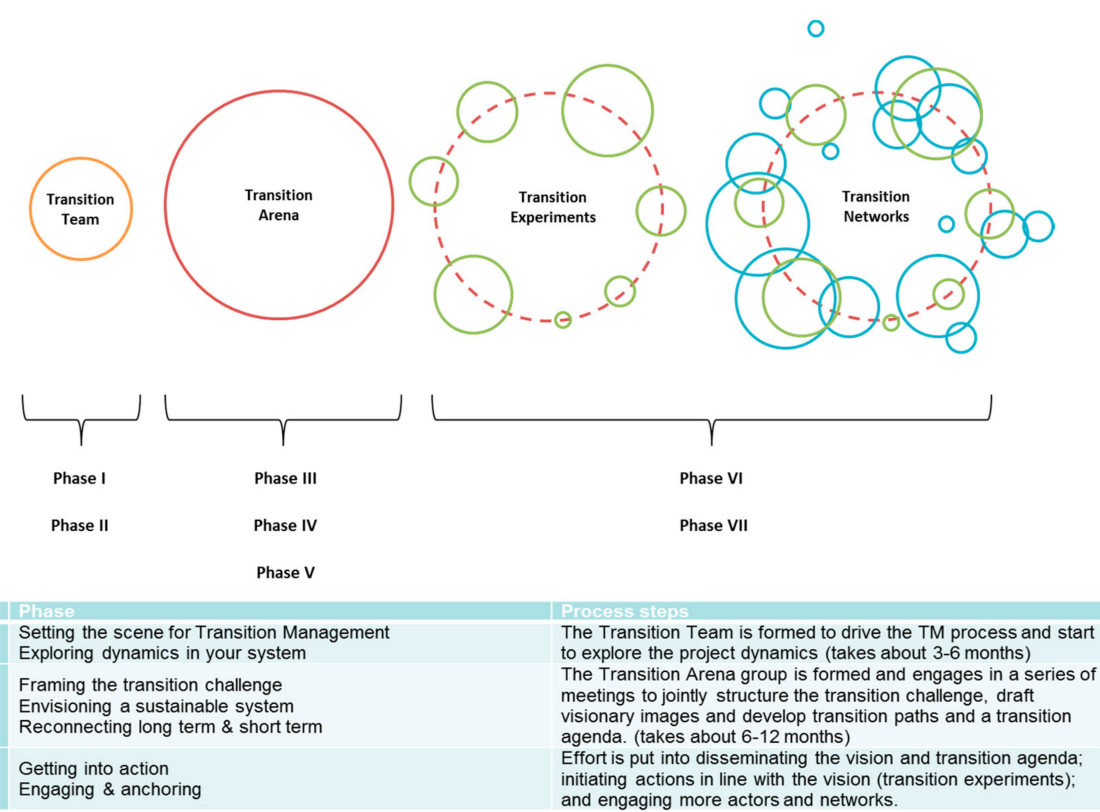

Figure 1. The outline transition arena process (adapted from Reference [37]). 
Transition management has originally been developed to support frontrunners to more strategically develop their alternatives to incumbent regimes through experimentation and envisioning [38]. Over time it has been applied in many different contexts and at different levels of scale, but not directly within the context of a regime (organisation). In this research, however, we experimented with applying transition management in an incumbent organisation operating in the context of a destabilising regime. As such, the aim of the TM (Transition Management) process was to develop a challenging narrative with a group of potentially influential change agents. This draws upon ideas also formulated by Avelino on informal power and its potential role in transitions [39]. Instead of seeking to destabilise a regime by mobilising niches, we experimented with implementing transition management to contribute to destabilisation from within the regime in order to accelerate the energy transition. Although elements of TM, such as backcasting (cf. References [40-42]), have been used to guide businesses confronted with impending transitions, to our knowledge, the current effort is the first example of a full-fledged TM process applied with an incumbent in the context of a destabilising regime. The adaptations we made to apply transition management in this particular context are discussed in Section 3 and we will reflect on them more elaborately in the concluding Section 5 .

\subsection{Transition Management in Practice}

Action research is central to transition management. While more traditional research efforts take pride in keeping analytical distance to the issues under study, action research holds that the best way to understand how things work is to directly engage and try to change them. Action research is distinguished from more traditional research in the sense that action researchers do more than just observing, reporting, analyzing, or evaluating. Action research means that we are involved in preparing and organizing meetings and engage in normative debates on sustainability. Constantly reflecting on the action-reaction dialectic, especially when done together with others that have an interest in the system under study, provides deep understanding and insights that would not have been attainable by staying at a distance. Furthermore, action research allowed us to design the research in such a way that it not only furthers scientific knowledge development, but was also helpful for the participants. For a more specific treatment of action research methodology and the demands it places on researchers, we refer to References [43-46].

Concretely, the action research activities revolved around strategy work commissioned by and in cooperation with the Port of Rotterdam Authority, taking place between January 2015 and March 2017. This cooperation came about after several years of rather dialectic relationships between the authors and the Port of Rotterdam: we have repeatedly and publically criticized the port for its weak sustainability performance (see e.g., References [47,48]), to the annoyance of some within the Port Authority, including the former CEO. Growing societal scrutiny of the port's performance together with a change in leadership at the Port Authority opened up space to involve us directly and as such get their critics onboard. Several meetings took place in advance of the actual transition management process with both the CEO of the Port Authority and the transition team, consisting of the authors and two representatives of the Port Authority's strategy department. These meetings focussed on developing the aims and content of the process as well as building mutual trust that this process could contribute to the port's sustainability objectives.

The action research efforts provided access to specific documents, interviewees and organizing strategy sessions with employees and relevant contacts within and outside the Port area. As such, the data sources include:

- Public documents, including annual reports and studies;

- Internal documents, including strategy documents, working documents and studies under progress, minutes of meetings and e-mail conversations;

- Field notes of participant observation in arena meetings;

- $\quad$ Field notes of informal (telephone) conversations; 
- Semi-structured interviews with:

- respondents at strategic positions within the Port Authority;

- other organisations in the Port of Rotterdam, which are also involved in the energy transition; and

- organisations outside of the Port, which were identified as interesting sparring partners in the energy, circular and bio-based transitions.

With the help of the Port of Rotterdam Authority, potential respondents and participants have been identified. A list of interviews is provided in Appendix A. Interview respondents were selected based on their strategic position within the organization, mostly board level, or from strategy or public affairs departments. Respondents are interviewed on personal title, and personal anonymity is granted in the presentation of results; therefore, when using quotes, only the organizational context is mentioned. It should be stressed though that the views provided are those of the respondents and not necessarily that of the organization they work for. Arena participants have been selected in order to include a diversity of backgrounds and departments within the Port Authority, and strategic and visionary capabilities of participants. The processing and analysing of data has been a deliberative effort that has taken place throughout the project. Insights from the interviews, desk research, meetings and sessions were constantly discussed, analysed and synthesised within the transition team, with the counterparts at the Port Authority and with the arena participants. The final results have been reviewed by our counterparts at the Port Authority upon which minor factual changes have been made.

\section{Transition Management in the Port of Rotterdam}

From January to March 2015, the transition management process has been prepared in close cooperation with the strategy department of the Port Authority. Figure 2 provides a timeline of the main steps in the transition management process. In cooperation with the Port Authority, a long list with respondents and potential arena participants was developed. Interviews with these respondents have been used to select participants and as input for the preparatory system's analysis, which formed the basis for the arena kick-off. In this section, we present a concise reconstruction of the process and its main results. Because of the sensitivity of the material, the results are anonymised. Furthermore, sensitivity and readability concerns forced us to be selective in reporting the results. More details on the specific parts of the process can be shared upon request (please contact the corresponding author atbosman@drift.eur.nl).
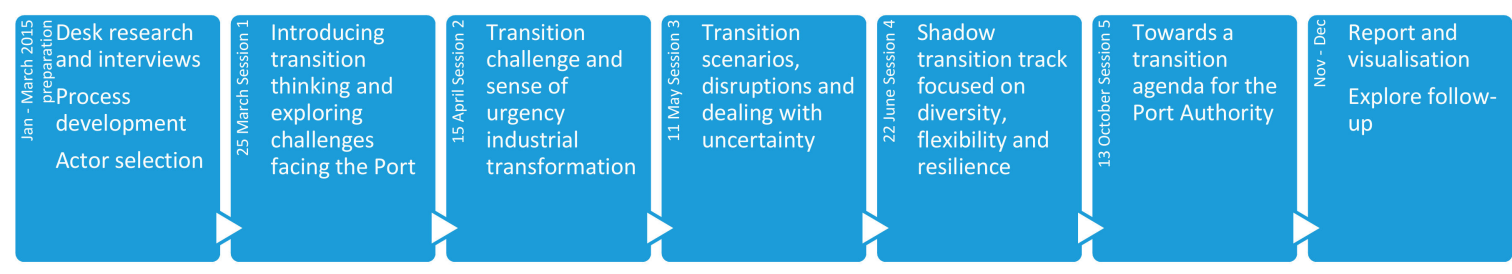

Figure 2. The timeline of the Port of Rotterdam transition arena.

\subsection{Systems Analysis}

The fossil-based energy regime in the port of Rotterdam is characterised by its focus on scale and volume and consequent cluster synergies [49]. The success of the port is measured in megatonnes transhipped [50]. Through its focus on volume, scale and developing the accompanying infrastructure requirements the port has been able to attract large-scale bulk petrochemical production, becoming a transhipment hub for high volumes of crude petroleum and derivative products, while developing into a large user of fossil fuels itself. Investments in R\&D are relatively low compared to the Dutch average [51]. This is partly explained by the fact that the petrochemical cluster and energy production 
is constituted by large multinationals whose headquarters and $R \& D$ departments are located elsewhere. The decision to invest and innovate in their assets in Rotterdam is part of a strategic consideration, also taking into account their operations in other countries and comparing the respective competencies and benefits. Furthermore, petrochemical operations are highly capital and infrastructure intensive, involving large investment sums, long depreciation periods and the accompanying risk-averse behaviour. On top of that, a large share of activities, such as plant maintenance, have been standardized and outsourced to SMEs over time. These SMEs then tend to focus on optimizing those standardized activities (interview 12). Added up, these elements lead to investment behaviour that is relatively conservative and risk-averse. The strengths of scale and cluster benefits which have developed over time form the premises for new investments along similar lines, resulting in a path-dependent development and lock-in of carbon intense activities [49].

\subsubsection{Landscape Pressures}

The context of this fossil energy regime in the port of Rotterdam is changing; after several decades of continual economic growth of international trade, the outlook for the coming decades is much more uncertain. Five landscape developments have been identified that, in particular, put pressure on the port of Rotterdam [52-54]:

1. Demand from Europe is stabilizing because its market is mature and its population is stable and ageing;

2. Refining increasingly takes place closer to the source, for example in the Middle East;

3. The shale gas revolution in the United States provides cheap feedstock and energy which increases the competitive position of the petrochemical industry across the Atlantic;

4. Increasing geopolitical concerns regarding fossil fuel dependencies, for example in Russia, challenge fossil fuel industries;

5. Increasing environmental concerns, in particular, climate change, challenge the future of fossil-based industries.

\subsubsection{Niche Pressures}

In response to these landscape trends, niches develop in and outside the port of Rotterdam which might, over time, challenge and provide an alternative to the existing regime. The most relevant niche developments are gathered under the umbrellas of the Bio Port initiative [55] and the Rotterdam Climate Initiative [56].

\section{Bio Port}

The port of Rotterdam harbours several activities related to the biobased economy. Especially in the production of first-generation biofuels, the port already plays a leading role. The main players in this area are Alco Energy and Neste, which operates the world's two largest bio-refineries, one of which is located in Rotterdam, and Bio-petrol. The port of Rotterdam is attractive for these producers because of the proximity to customers, mostly traditional fossil fuel producers which are required to blend biofuels into their petrol and diesel according to the EU fuel directive, and because of the available infrastructure and logistical channels (interview 11). The global biodiesel market totalled about 10 megatons in 2013 [57], of which 1.45 megatons is produced in the port of Rotterdam [58]. However, this is still only a fraction of the 60-megaton fossil fuel refining capacity of the port.

\section{Rotterdam Climate Initiative (RCI)/Energy Port}

The RCI, a joint initiative between the municipality and the Port authority, started in 2007 with the goal of halving the $\mathrm{CO}_{2}$-emissions of Rotterdam (city and port area) by 2025 compared to 1990 levels. In 2013, RCI presented its energy action plan consisting of seven focus areas of which five relate to the fossil cluster in the port, including the Bio Port already mentioned above. The other four are: 
- Deltaplan energy infrastructure, focusing on developing infrastructure to transport and reuse heat, steam and $\mathrm{CO}_{2}$;

- $\quad$ Setting up of an expert centre for energy efficiency, in which the test facilities for sustainable process technology, PlantOne, located in the port played an important role;

- Stimulating the use of liquefied natural gas (LNG) in water and road transport, reducing its $\mathrm{CO}_{2}$-footprint compared to traditional fuels;

- $\quad \mathrm{CO}_{2}$ capture and storage (CCS) from new coal-fired power plants.

However, 10 years into the $\mathrm{RCI}$, we have to conclude that instead of a decrease of $\mathrm{CO}_{2}$-emissions, the Port of Rotterdam is rather on track towards a $50 \%$ increase in 2025, because carbon capture and storage (CCS) which had a large role in the RCI did not materialize.

In addition to the developments gathered under the RCI and Bio Port umbrellas, the port of Rotterdam boasts several initiatives focused on developing and attracting the wind industry, both on- and offshore and on co-firing biomass in coal-fired plants [59]. Next to these alternatives developed within the port, the rise of hybrid and electric vehicles impacts demand for the ports main petrochemical products [60]. Table 1 summarizes the landscape and niche-induced pressures on the fossil energy regime in the port of Rotterdam.

Table 1. The pressures on the fossil energy regime in the port of Rotterdam.

\begin{tabular}{cc}
\hline Landscape Pressures & Niche Developments \\
\hline Stabilizing demand in Europe & Bioport \\
Increased refining at source & Rotterdam Climate Initiative \\
U.S. shale gas revolution & Renewable energy \\
Geopolitical concerns & Electric mobility \\
Environmental concerns & \\
\hline
\end{tabular}

\subsubsection{Role of the Port of Rotterdam Authority}

The Port of Rotterdam Authority is a semi-public organisation that is responsible for the smooth operation of the Port. It takes care of the development, construction, management and operation of the Port industrial complex as well as ensuring the effective, safe and efficient handling of shipping and the offshore approaches to the port. Its objective is to enhance the port's competitive position as a logistics hub and world-class industrial complex [61]. Its shareholders are the municipality of Rotterdam (70\%) and the Dutch government (30\%). It had 1150 employees and a turnover of $€ 712$ million in 2017 [50]. The key revenues come from rental income and port dues. Furthermore, the Port of Rotterdam Authority lets port sites, primarily to storage and transhipment companies and to the chemical and petrochemical industries and energy producers. It imposes port dues on ships that make use of the port. It invests in public infrastructures, such as roads in the port area, in customer-specific infrastructures, such as quay walls and jetties, and in the development of new port sites. In order to handle shipping as effectively as possible, it also invests in a traffic management system, patrol vessels and emergency control [61].

From the preparatory interviews at the start of the transition management process, a picture emerges of a responsible caretaker. Metaphors of a landlord and shopping mall manager are used to describe its role. The Port Authority takes care of the shared infrastructure and a sound investment climate for the industries in the port. It generally does not have an opinion on the organisations and activities that set up shop in the port. Additionally, respondents are critical of the influence their organisation could exercise in the transition:

"Politics should decide the direction, the Port Authority will follow." ( . . ) "We should focus on what we are good at, business-case-driven, not ideological." (interview 7)

"We can't get too far ahead of the pack, we need to take them along." ( ... ) 
"We could stimulate a bit with harbour dues, but the factories are not ours, so we should not overestimate our influence" (... ) Also, it is difficult to say: 'this ship can't come in', because then it will go elsewhere. What we can say is: 'the most sustainable ship receives a discount'." (interview 9)

\subsection{Port of Rotterdam Transition Arena}

The Port of Rotterdam Transition Arena consisted of a series of five workshops spread out over about a year, with 15 participants from different departments within the organization, from strategy to pilotage, and finance to environmental compliance. The participants were selected based on their interest in transitions, their strategic and visionary capabilities, their specific positions within their departments and a representation of the different specialities within the organisation.

The first session focused on introducing transition thinking and exploring the developments in the environment of the Port, using the multi-level perspective as a lens. Based on the preparatory systems analysis, we discussed the relevant landscape and niche developments facing the Port and the regime characteristics. This led to insights in the transitional pressures facing the Port and questions about the role of the Port Authority: is it merely a manager, or should it also take a more directive role aimed at a desired future for the port?

The outcomes of the session have been used to sharpen the systems analysis (as elaborated in Section 3.1) and reflecting on the discussions within the group made us realize that the sense of urgency for transformative change was quite low. It was challenging for the group to think in terms of disruptive change and to envisage a radically different port. With this in mind, we chose to deepen the problem structuring further in the second session.

In the second meeting, we translated the outcomes of the first session into a transition challenge for the Port. We confronted the group with an exploration of how other industrial areas, such as the car and steel industry in the United States, the mining industry in the South of the Netherlands and imaging company Kodak have transformed or declined in the past. Figure 3 provides a schematic overview of different possible transformation pathways. From this discussion, it became clear that there is a real chance that parts of the port of Rotterdam might turn into industrial wastelands. This resulted in a larger sense of urgency to search for and work on alternatives within the group.

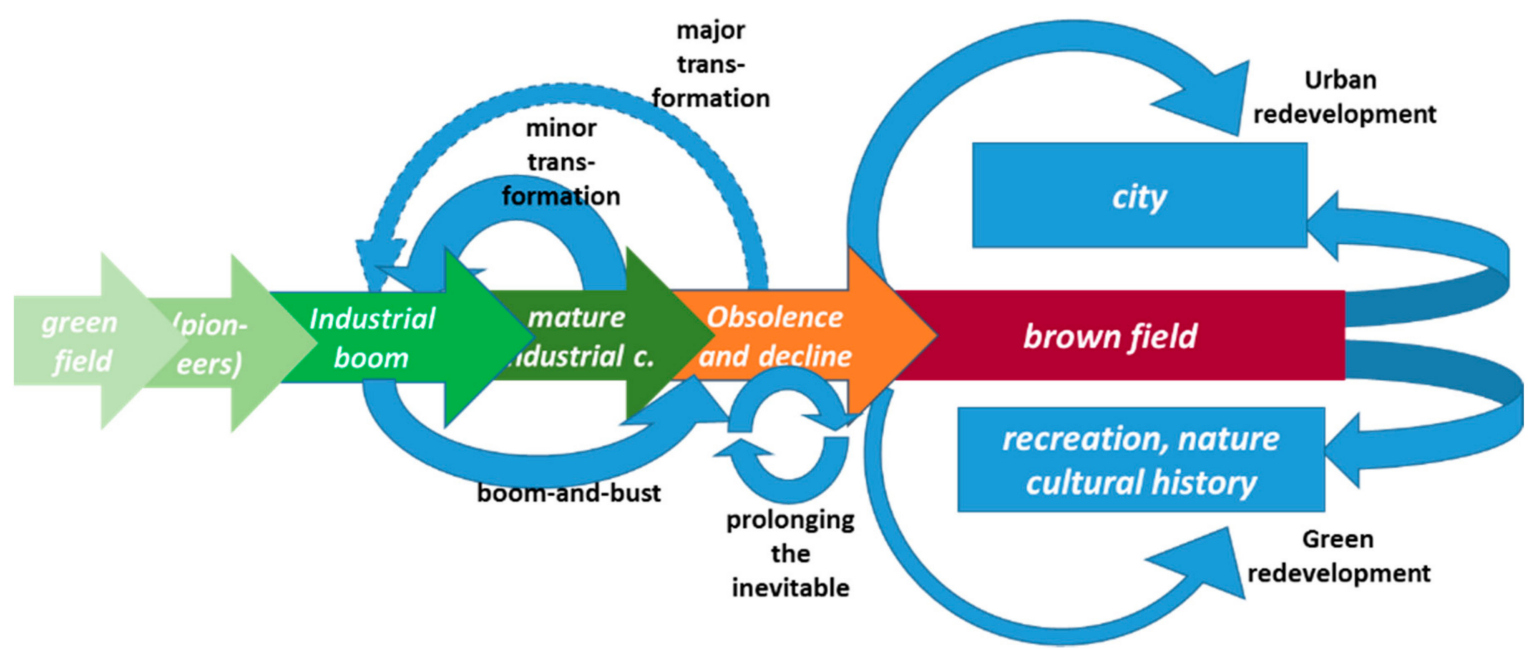

Figure 3. The industrial transformation pathways over time.

Based on discussions between the transition researchers and the participants, the transition challenge was formulated as follows:

how to transform from a linear to a circular port economy, from fossil to bio-based and from a monoculture based on three isolated pillars (logistics, maritime industry, energy and chemistry) to a diverse and flexible industrial ecosystem? 
Reflecting on the first and second sessions within the transition team, it was time to think about the future of the port. Realizing that it proved difficult to think in radically different alternatives and disruptions, we decided to use the existing energy scenarios of the Port Authority, which are familiar to participants, and to test these scenarios against disruptions and unexpected events.

As such, the third session focused on transition scenarios, disruptions and dealing with uncertainties. We introduced scenarios as a thinking exercise to explore different futures and to see whether the port was prepared for such a future. In a workshop setting, we confronted the Port's own scenarios with several disruptions, such as hyperinflation, a food crisis, a trade boycott with Russia and China, a global climate agreement (this was before Paris!) and the emergence of methane-hydrates as a new energy source, with the question, what do these disruptions mean for the Port? Additionally, in which of the existing scenarios are you best prepared to deal with this disruption? Initially, the exercise led to some confusion. The primary responses were that these disruptions were imaginary and unrealistic. However, the only relevant question was, imagine something like this happens, are you prepared to deal with it? Once this became clear, intense discussions and creativity emerged. One of the striking findings was that the group could more easily imagine a trade boycott with Russia than a binding global climate agreement. The experiences from the workshop were then used to have a discussion on different types of disruptions and uncertainties, and how to deal with these.

In the fourth session, we consolidated the findings from the previous sessions. Over the course of the workshop series, it became clear to participants that the port was facing existential pressures in all of its traditional pillars. Together, we translated this into a more elaborate transition challenge:

The Port of Rotterdam forms a fossil monoculture focusing predominantly on mass, volume, scale and technological solutions. Considering a rapidly changing environment, this presents existential risks for the future of the Port. The Port Authority has only a partial and fragmented answer to these challenges. Therefore, a transition track is needed to build a coherent alternative shielded from the direct influence of the regime. Diversity, flexibility and resilience should be the leading principles in this shadow track and the focus shifts to the added economic, social and ecologic value of the activities in the Port.

Then, we moved on to potential directions to deal with these challenges and the role the Port Authority could take in that. Here, we again encountered an ambivalent stance: Is the Port Authority a playing ball of these global developments, or is it possible or even necessary to take a more pro-active role? The conclusion was that the Port Authority has no control over those developments, but does have possibilities to create the conditions that enable and accelerate desirable activities or discourage unwanted ones.

We confronted participants with several dilemmas revolving around the issues floated in previous sessions to flesh out where the real pain is or might be. These dilemmas made the issues of volume growth vs. added value, strengthening the existing monoculture vs. promoting diversity and technological vs. social innovation tangible and forced participants to take sides. Reflecting with the participants on these dilemmas, it became clear that they were broadly recognized, but that most participants tended to choose familiar options with which they reproduce the traditional focus on mass and volume, scaling and technological solutions. The dilemma exercise helped in making these often-implicit preferences explicit to the group.

To conclude the session, these insights were then translated into a transition 'shadow-track' for the Port Authority, with new guiding principles of diversity, flexibility and resilience, as opposed to those of mass, volume and scale. Furthermore, the idea emerged to develop a transition unit, consisting of a team of pioneers, that would coordinate and further develop this transition track for the Port.

The fifth and last session focused on further developing the transition agenda for which the foundations were laid in the previous session. This time, with a particular focus on the role of the Port Authority. From the discussions, it became clear that the Port Authority is a rather traditional, 
hierarchical organisation. Whereas a diverse, agile and resilient company that is able to nurture creativity and innovation is needed to lead the transition. This forms a huge challenge because the Port Authority itself mirrors the port in terms of a culture that is focused on volume, growth and optimisation of the existing system, through technological innovation. Given the increased pressure and disruptions facing the port, it is increasingly risky to work on the assumption of an orderly world in which a solid business case for an all-encompassing 'plan A' can be made, based on the expected volume growth. Participants concluded that they collectively had a 'mental vacuum' with regards to imagining futures that are structurally different from how the Port is organized today. In other words: they could envisage biofuels developing to the scale of fossil fuels over decades, but not a future with much fewer fuels and completely different or a much higher diversity of activities. The narrative that was developed during the TM process has been visualized (see Figure 4) in order to summarize it, as well as to help participants to communicate it outside of the arena group. The visualisation included the key elements of the transition narrative:

- The destabilisation of the current fossil regime

- The systemically different future in terms of structures, resources and organisation

- $\quad$ The mental vacuum with regards to the transition pathway

- $\quad$ The need to experiment based on guiding principles

- $\quad$ The need to 'cut loose' such experimentation to make it transformative

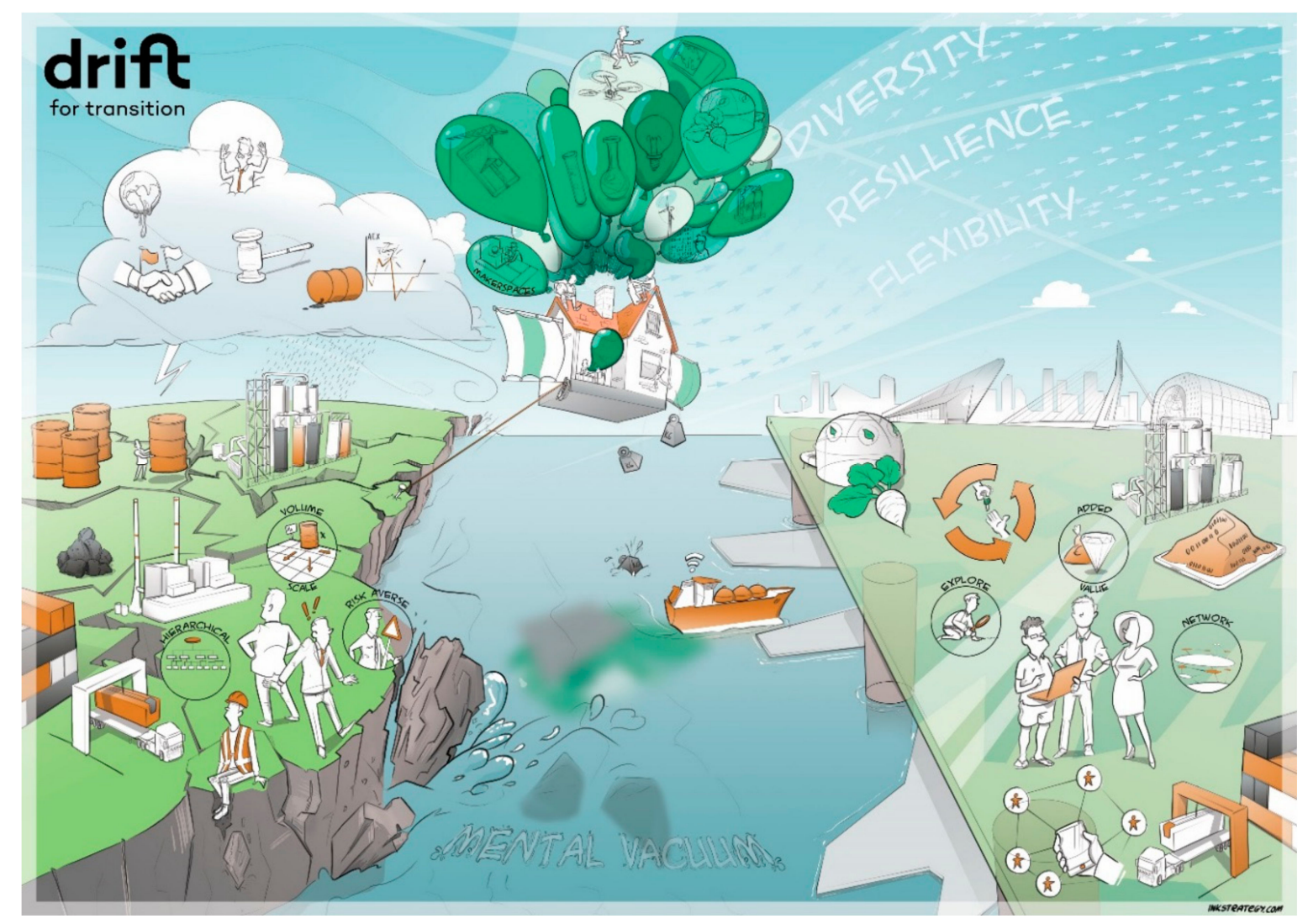

Figure 4. The visualisation of the Transition agenda 'towards a diverse, flexible and resilient Port of Rotterdam' (in cooperation with InkStrategy).

The transition arena subsequently agreed that a transition shadow track should support the internal transition within the Port Authority, as well as the transformation of the whole port of Rotterdam (see Table 2). Within this track, experimentation can take place on a small scale, to find 
answers to the challenges laid out above. In the last session, together with the participants, we have developed a long list of actions for the Port Authority, categorized in an internal and external broadening agenda and a deepening agenda, and in what is already happening and what needs to happen in the future.

Table 2. The transition shadow track towards a diverse, flexible and resilient Port of Rotterdam.

\begin{tabular}{|c|c|c|c|}
\hline Leading Principles & Baseline & Direction of Solution & Transition Track \\
\hline \multirow{6}{*}{ Diversity } & $\begin{array}{l}\text { Industrial activities are } \\
\text { very dependent on } \\
\text { fossil resources }\end{array}$ & $\begin{array}{l}\text { Multiple tracks for } \\
\text { industrial activities }\end{array}$ & $\begin{array}{c}\text { Develop and advocate a vision for } \\
\text { a long-term green } \\
\text { industrial complex }\end{array}$ \\
\hline & $\begin{array}{l}\text { Little (cultural, social, } \\
\text { professional) diversity of } \\
\text { people in the Port }\end{array}$ & $\begin{array}{l}\text { Diversity in employees, } \\
\text { languages and cultures }\end{array}$ & $\begin{array}{l}\text { Diverse, multi-cultural } \\
\text { transition teams }\end{array}$ \\
\hline & $\begin{array}{l}\text { Clusters dominated by } \\
\text { a handful of large } \\
\text { multinationals }\end{array}$ & $\begin{array}{l}\text { Industrial ecosystems of small, } \\
\text { medium and large businesses }\end{array}$ & $\begin{array}{l}\text { Five transition 'playgrounds' in } \\
\text { which change-minded incumbents } \\
\text { cooperate with innovative } \\
\text { newcomers to show } \\
\text { sustainable innovation }\end{array}$ \\
\hline & $\begin{array}{l}\text { Closed shop (benefitting } \\
\text { existing players) }\end{array}$ & $\begin{array}{l}\text { Attract new entrants and } \\
\text { connect to sustainability } \\
\text { challenges of existing industries }\end{array}$ & $\begin{array}{c}\text { Flying brigade pro-actively scouting } \\
\text { new leads in foreign (to the Port) } \\
\text { sectors }\end{array}$ \\
\hline & $\begin{array}{c}\text { Focus on a small number } \\
\text { of large flows }\end{array}$ & $\begin{array}{l}\text { Focus on multiple streams and } \\
\text { active development and use of } \\
\text { side/waste flows }\end{array}$ & $\begin{array}{c}\text { Make (waste)flows transparent to } \\
\text { outsiders }\end{array}$ \\
\hline & $\begin{array}{l}\text { Port and city have } \\
\text { grown apart }\end{array}$ & $\begin{array}{l}\text { Use ports close to the city to } \\
\text { restore links and exchanges }\end{array}$ & $\begin{array}{l}\text { Work on attractiveness and strategic } \\
\text { use of city ports }\end{array}$ \\
\hline \multirow{4}{*}{ Flexibility } & $\begin{array}{l}\text { Developing } \\
\text { infrastructure in the very } \\
\text { long-term and for } \\
\text { single customer }\end{array}$ & $\begin{array}{c}\text { Phased development of } \\
\text { infrastructure aimed at multiple } \\
\text { users and uses }\end{array}$ & $\begin{array}{l}\text { Transition backbone for heat, } \\
\text { resources, data, electricity } \\
\text { and mobility }\end{array}$ \\
\hline & $\begin{array}{l}\text { Every company has its } \\
\text { own machinery, which } \\
\text { stands idle for most of } \\
\text { the time }\end{array}$ & Strategic sharing of hardware & $\begin{array}{l}\text { Develop sharing platform for assets } \\
\text { including insurance }\end{array}$ \\
\hline & $\begin{array}{l}\text { Slow and rigid decision } \\
\text { making laid out } \\
\text { in contracts }\end{array}$ & $\begin{array}{c}\text { Space for flexible contracts and } \\
\text { creative use of greater } \\
\text { environmental freedom }\end{array}$ & $\begin{array}{l}\text { Substantive vision for the future of } \\
\text { the Port guides priorities and leads }\end{array}$ \\
\hline & $\begin{array}{l}\text { Port Authority is } \\
\text { organised in silos }\end{array}$ & Matrix structure & $\begin{array}{c}\text { Flat organisation with flexible } \\
\text { thematic clusters }\end{array}$ \\
\hline \multirow{4}{*}{ Resilience } & $\begin{array}{l}\text { Betting everything on } \\
\text { one horse }\end{array}$ & $\begin{array}{l}\text { Having a backup plan, focused } \\
\text { on a broad portfolio of } \\
\text { robust solutions }\end{array}$ & $\begin{array}{l}\text { Transition strategy with room for } \\
\text { failure and learning; asking clients } \\
\text { for their plan B }\end{array}$ \\
\hline & $\begin{array}{l}\text { 'Anything goes' } \\
\text { in the Port }\end{array}$ & Commit and dare to choose & $\begin{array}{l}\text { Port Authority has an opinion on } \\
\text { activities based on a substantive } \\
\text { vision for the future }\end{array}$ \\
\hline & $\begin{array}{l}\text { Short-term profit } \\
\text { maximisation }\end{array}$ & $\begin{array}{l}\text { Investing in what is needed for } \\
\text { the future }\end{array}$ & $\begin{array}{c}5 \% \text { of budgets to transition track, } \\
\text { without a target for returns } \\
\text { to be made }\end{array}$ \\
\hline & $\begin{array}{l}\text { A narrow focus on } \\
\text { volume and growth }\end{array}$ & $\begin{array}{l}\text { Broad focus on added economic, } \\
\text { ecologic and social value }\end{array}$ & $\begin{array}{l}\text { Develop transition indicators which } \\
\text { are taken into account when } \\
\text { investing, e.g., not fossil; local } \\
\text { solidarity; societal value }\end{array}$ \\
\hline
\end{tabular}

In developing this shadow track, with its short-term actions, transition governance returns to the idea of 'evolutionary revolutions' (Rotmans et al., 2001): the transition arena process provided a new radical future orientation to guide short-term, often incremental and manageable actions. As transitions are unpredictable and impossible to manage top-down, especially on a very long time-horizon, transition management is all about strategic experimentation and reflexivity based on a radical ambition to work towards systemic change. 


\section{Effects on the Port Authority's Strategy and Practice}

In this section, we reflect on the repositioning of the Port Authority over the course of the transition management process. Where initially employees of the Port Authority saw few possibilities for their organization to influence the transition (see Section 3.1.3), after completion of the process, we see several indications that it is taking a more proactive role in the energy transition. While it is difficult to establish whether this repositioning is caused directly by the transition management process, we will indicate where possible how the process had its impact.

\subsection{Transition Narrative and Strategy}

After the transition arena, the Port Authority started taking on a much more proactive narrative of 'transforming the old and creating space for the new' which has been adopted publicly by the CEO as 'the direction of the inevitable transition' [62]. It is advocating this narrative through different media and at high-level meetings and conferences, including the National Climate Summit, organised by the Dutch government to translate the goals of the Paris agreement to the Netherlands [63].

Recently, the narrative has become even tougher, with the CEO of the Port Authority saying that those 'who do not want to join should leave the Port.' [64], leading to tensions with existing fossil-based industries in the Port [54,65]. Additionally, the Port Authority has started its own series of conferences to put the issue on the (political) agenda: the Energy in Transition Summit (2018).

\subsection{Organisational Structure and Investments}

Next to changing its narrative, the Port Authority decided to invest heavily in terms of personnel and financial means. It has developed a transition unit of $50 \mathrm{FTE}$ to pursue businesses and activities that could contribute to making the transition. The team will 'offer support with attractive accommodation conditions, connecting infrastructure, support with permit applications and finding financing, etc.' [55].

While most resources had so far been invested in logistical and industrial infrastructure, such as quays and pipelines, more recently it is increasingly focused at opportunities to incentivize social and institutional innovation, including funding for start-up hubs and maker spaces. 'When it comes to crucial investments to realise the energy transition, the Port Authority is also prepared to make its own risk-bearing investments or to participate in companies' [55]. Furthermore, specific developments are incentivized with other than monetary means, such as setting aside specific locations for bio-based developments and providing infrastructure in a 'plug and play' manner.

\subsection{Partnerships and Practices}

Where traditionally the existing industries and businesses in the Port were the natural partners, anticipating a transition requires different ways of interacting with stakeholders and engaging with new partners. Part of changing the narrative is to position the Port Authority for new partnerships with actors that pursue a similar agenda and to reassess its ongoing cooperations. A concrete example of the new ways in which the Port Authority is interacting with its existing and new stakeholders in the Biobased Port Transition Arena that has been executed as a follow-up from the internal Transition Arena with the same transition team complemented with the Director Energy and Industry of the Port Authority. This transition arena process focused on co-creating a vision and transition-agenda towards a bio-based and circular Port of Rotterdam with actors from within the port and frontrunners from outside the port [66]. As such, it constituted a mutual searching and learning process to explore the alternative futures for the Port, for which the internal arena process laid the foundations.

However, while the changes set out above seem promising, recent developments around coal logistics in the Port show the limits of current ambitions: a research journalist unearthed the fact that a permit for the largest coal transhipment company in Europe, Europees Massagoed Overslag bv (EMO) will expire in the summer of 2018 and that it would like the permit to be renewed [67]. This led to discussions amongst citizens and the municipality, the majority owner of the Port Authority, took on 
a resolution to phase out coal in the Port. In response, the Port Authority claimed that it is unable to do anything about the renewal of the permit.

In conclusion, we observe that the Port Authority is slowly changing its role, but it is still split between two orientations: it is increasingly stimulating the new economy, diversifying its organisation and setting up a transition team and data department, but has not yet quit supporting the old economy. In the transition arena, we positioned the transition strategy in terms of AND/AND, meaning a focus on the break-down of the old economy and the build-up of new circular and biobased alternatives. The break-down of the old economy in line with the Paris agreement would entail closing all coal-fired power plants and related logistics, halting investments in new refineries or fundamental refurbishing of existing ones and a repurposing of related infrastructure and storage facilities for the bio-economy. The build-up of a circular and bio-based port would entail large-scale investments in system innovations, such as anaerobic fermentation for bio-based chemistry, hydrogen production and infrastructure and the reuse of $\mathrm{CO}_{2}$. The Port Authority has translated this break-down and build-up strategy foremost into an AND old economy AND new economic strategy. On top of that, the focus seems to be predominantly on system optimisation, for example through carbon capture and storage, instead of being on system innovation for sustainable low-carbon production. Additionally, the leadership is ambiguous, detailing strong ambitions, but when it comes to execution, the unavoidable pain is postponed rather than confronted, as in the case of EMO.

\section{Reflections and Conclusions}

In this paper, we presented the results of a transition management process with the Port of Rotterdam. It is the first time that transition management has been applied in close cooperation with an incumbent organisation operating in the context of a regime that is increasingly under pressure and destabilizing. Applying transition management in this context shows that transitions thinking and transition management also have something to offer in such a context. Introducing thinking in terms of disruptions and uncertainties has helped the Port Authority to think in alternative futures and disruptions for the Port of Rotterdam and to diversify its actor networks. Furthermore, where the Port Authority initially saw little potential for influencing the energy transition, applying transition management, together with other trajectories running at the Port Authority has contributed to a change in attitude and diversifying its strategy by opening up new avenues of influence.

Furthermore, while it is not an explicit aim, applying TM with incumbents operating in a regime context draws attention to destabilisation dynamics. It contributed to challenging the existing dominant culture, structure and practices in the Port through:

- bringing into view the transformative challenges facing the Port through co-creating a systems analysis;

- sensitizing participants to potential disruptions and uncertainties facing the Port, through confronting them with wildcard developments, dilemmas, other actors with alternative perspectives and exploring alternative futures;

- explicating underlying assumptions about the raison d'être of the Port (volume and mass) and the role of the Port Authority, enabling discussion of the applicability of these assumptions in a changing context;

- highlighting relevant niche-developments within and outside the Port to sensitise participants to sustainable alternatives that are already available;

- diversifying existing actor networks and changing its interactions with stakeholders, by inviting actors from other domains and niches to collectively explore alternative futures;

- creating space for open discussion, challenging each others' ideas and assumptions, allowing vulnerability and doubt.

Challenging ingrained views and assumptions proved necessary and instrumental in order to allow for more systemic experimentation with sustainable alternatives in a context of decreasing certainties. As such, transition management has contributed to destabilising the fossil fuel regime 
in the Port of Rotterdam, while, at the same time, supporting the Port Authority to take a more pro-active role in the transition. We observe a change in the culture and understanding of its role within the Port Authority towards one that is more pro-actively oriented towards the new economy. Increasingly within the Port Authority, there is the perception of two streams, one focused on the 'old economy' and one on the new, of which the latter gains increasing importance, especially amongst the younger employees.

Furthermore, our action-research in the Port of Rotterdam has contributed to the understanding of the inner workings of regimes and the role of agency in their destabilisation. Since this has been an explorative paper based on a single case study, we formulate our insights as propositions that should be verified and further developed in subsequent research:

a. While existing research puts the emphasis on external factors causing regime destabilisation (e.g., References $[19,21]$ ), our research shows that incumbent repositioning is another important driving force, in which external factors play a role, but also internal ones, such as changes in leadership, culture and the influx of a more diverse workforce, including younger people and more women. Further research could investigate the effects of incumbent repositioning on the stability of regimes, e.g., how does incumbent repositioning affect regime stability? Additionally, which factors enable or constrain such repositioning?

b. In response to landscape tensions and niche pressures, some incumbent actors are able to change their position vis-a-vis the regime through changing discourse, roles, networks, redirecting of resources and developing new practices. Further research could verify whether this repositioning repertoire is exhaustive or whether other types of repositioning play a role;

c. Changes in discourse precede those in networks, resources and particularly practices. Further research could verify whether this order in changes is particular to the Port Authority or whether this pattern is more widespread in incumbent repositioning;

d. In repositioning, focusing on build-up is easier or more attractive than on breakdown. From a transitions perspective, however, break down is also necessary and effective, as a combined focus on build-up and breakdown could lead to faster results. Further research could shed light on whether build-up is indeed more attractive than breakdown for incumbent actors and the reasons why this is the case;

e. Incumbent repositioning leads to tensions in existing relations and institutions., which further drive regime destabilisation.

Furthermore, in order to verify these propositions, our work could be compared to other experimental interventions aimed at supporting incumbents to reposition themselves in the face of transitional pressures, such as Energy Futures Labs in Canada and backcasting at Electrolux and IKEA, amongst others [40-42].

In sum, we conclude that the Port Authority is indeed taking a more proactive role supported by the transition management process and that this intervention indeed led to a number of significant structural, discursive and practical changes that helped guide and accelerate a possible transition. However, we also conclude that the dominant strategy still is to combine business-as-usual with the transition 'shadow track'. It is obviously impossible to shift overnight from business-as-usual to a completely fossil free port, but its current development and overall strategy are still not in line with the Paris climate agreement.

Author Contributions: Conceptualization, R.B.; Funding acquisition, J.R.; Investigation, R.B., D.L., J.R. and R.v.R.; Methodology, D.L.; Project administration, R.v.R.; Supervision, D.L. and J.R.; Visualization, R.v.R.; R.B. Writing — original draft, R.B.; Writing—review \& editing, D.L., J.R. and R.v.R.

Funding: We are thankful to the Netherlands Organisation for Scientific Research (NWO) for funding this research under the "TRAPESES" research programme (2014-2018) (408-13-029) and the Port of Rotterdam Authority for funding the transition management process. 
Acknowledgments: While the Port Authority and Ruud Melieste, Victor Schoenmakers and Nico van Dooren, in particular, have played a crucial role in co-creating the transition management process, the results as presented in this paper are the sole responsibility of the authors. This paper has been partly based on the reports 'Transitie-arena Havenbedrijf Rotterdam: Naar een flexibele, diverse en veerkrachtige haven' [68] and 'Transitie-agenda biobased en circulaire haven Rotterdam' [66] authored by the same authors as this paper, based on discussions with the participants. The authors wish to thank the respondents who have taken time to answer our questions, and the participants in the two transition arenas who have accompanied us on this research journey and from whom we have learned an immense deal about the port industrial complex and bio-based circularity in practice. Furthermore, we would like to thank InkStrategy for visualizing the transition narrative. Earlier versions of this paper have been presented at the 8th ETH PhD-Academy on Sustainability and Technology in Switzerland 4-9 June 2015, the 7th International Conference on Sustainability Transitions (IST) in Brighton, United Kingdom 25-28 of August 2015, a research seminar at the Centre for Technology, Innovation and Culture (TIK) of the University of Oslo on the 11th of January 2016 and the 9th International Conference on Sustainability Transitions (IST) in Manchester, United Kingdom 11-14 June 2018. The authors wish to thank the participants in these workshops for their valuable comments, especially Charlene Zietsma, Laura Diaz Anadon, Cherelle Eid, Volker Hoffmann and Joern Hoppmann at the ETH PhD-Academy; Gijs Diercks, Bruno Turnheim and Steve Williams at the IST conferences and Håkon Endresen Normann and Olav Wicken at the TIK seminar. Furthermore, we would like to thank Gerbert Hengelaar and three anonymous reviewers for commenting on earlier versions of the paper.

Conflicts of Interest: The authors declare no conflicts of interest

$\begin{array}{ll}\text { Abbreviations } \\ \mathrm{CCS} & \text { Carbon Capture and Storage } \\ \mathrm{CEO} & \text { Chief Executive Officer } \\ \mathrm{CO}_{2} & \text { Carbon dioxide } \\ \mathrm{EMO} & \text { Europees Massagoed Overslag bv } \\ \mathrm{FTE} & \text { Full-time Equivalent } \\ \text { LNG } & \text { Liquified Natural Gas } \\ \text { NWO } & \text { Netherlands Organisation for Scientific Research } \\ \text { RandD } & \text { Research and development } \\ \text { RCI } & \text { Rotterdam Climate Initiative } \\ \text { TM } & \text { Transition management }\end{array}$

Appendix A. Overview Interviews

Table A1. Stage 1: 12 Interviews.

\begin{tabular}{cccc}
\hline & Position & Organisation & Date \\
\hline 1 & Director Public Affairs and Communication & ExxonMobil Benelux & $28 / 04 / 2015$ (telephone) \\
2 & Manager Energy Transitions & Shell & $15 / 06 / 2015$ \\
3 & Head Government Affairs & BP Netherlands & $17 / 06 / 2015$ \\
4 & Director Energy & Akzo Nobel & $27 / 05 / 2015($ telephone) \\
5 & Managing Director & Neste Oil Netherlands & $19 / 06 / 2015$ (telephone) \\
6 & Manager Corporate Strategy and Responsibility & E.on Benelux & $26 / 05 / 2015$ \\
7 & Senior Project Leader PorInt & Port of Rotterdam Authority & $19 / 03 / 2015$ \\
8 & General Manager Port Development and Management & Port of Rotterdam Authority & $18 / 03 / 2015$ \\
9 & Innovation Manager & Port of Rotterdam Authority & $18 / 03 / 2015$ \\
10 & Treasurer & Port of Rotterdam Authority & $19 / 03 / 2015$ \\
11 & Business Manager Chemical and Biobased Industry & Port of Rotterdam Authority & $17 / 04 / 2015$ (telephone) \\
12 & Director & iTanks foundation & $30 / 04 / 2015$ \\
\hline
\end{tabular}


Table A2. Stage 2: 21 interviews.

\begin{tabular}{lccc}
\hline & Position & Organisation & Date \\
\hline 13 & General Counsel & Deltalinqs & $31 / 03 / 2016$ \\
14 & Public Affairs Manager Energy Transition & Gasunie & $22 / 03 / 2016$ \\
15 & Director & Clean Tech Delta & $17 / 03 / 2016$ \\
16 & Programme Manager Biobased Economy & Ministry of Economic Affairs & $28 / 04 / 2016$ \\
17 & Project manager Strategy and scenarios at Shell & Shell & $10 / 05 / 2016$ \\
18 & Director Bio-Industrial Segment & Cargill & $21 / 04 / 2016$ \\
19 & CEO & ICO Nitrogen & $29 / 03 / 2016$ \\
20 & General Manager & North Seaweed & $24 / 03 / 2016$ \\
21 & Programme Manager Bio-Economy & ZLTO & $03 / 05 / 2016$ \\
22 & Senior Strategy and innovation adviser & Rabobank Rotterdam & $16 / 03 / 2016$ \\
23 & VP Biobased Innovations & Corbion & $04 / 05 / 2016$ \\
24 & Managing Director & Neste Oil Netherlands & $31 / 03 / 2016$ \\
25 & Founder and CEO & The Better Future Factory & $09 / 03 / 2016$ \\
26 & Director (VP) RandD & Suikerunie & $15 / 04 / 2016$ \\
27 & Managing Director & Europees Massagoed Overslag & $14 / 04 / 2016$ \\
28 & Managing Director & Eneco Business & $14 / 04 / 2016$ \\
29 & Innovation Manager Food and Biobased Research & Wageningen University & $16 / 03 / 2016$ \\
30 & President & Vopak Nederland & $22 / 03 / 2016$ \\
31 & Vice President Fuels & Lyondell Basel & $20 / 04 / 2016$ \\
32 & Distinguished Professor Biobased Economy & TU Delft & $10 / 03 / 2016$ \\
\hline
\end{tabular}

\section{References}

1. United Nations Framework Convention on Climate Change (UNFCCC). COP21 Adoption of the Paris Agreement. 2015. Available online: http://unfccc.int/resource/docs/2015/cop21/eng/109.pdf (accessed on 21 January 2016).

2. Global Carbon Project (GCP). Carbon Budget and Trends. 2017. Available online: www.globalcarbonproject. org/carbonbudget (accessed on 10 May 2018).

3. Pachauri, R.K.; Allen, M.R.; Barros, V.R.; Broome, J.; Cramer, W.; Christ, R.; Church, J.A.; Clarke, L.; Dahe, Q.; Dasgupta, P.; et al. Climate Change 2014: Synthesis Report. Contribution of Working Groups I, II and III to the Fifth Assessment Report of the Intergovernmental Panel on Climate Change; IPCC: Geneva, Switzerland, 2014; p. 151.

4. McGlade, C.; Ekins, P. The geographical distribution of fossil fuels unused when limiting global warming to $2{ }^{\circ}$ C. Nature 2015, 517, 187-190. [CrossRef] [PubMed]

5. Grin, J.; Rotmans, J.; Schot, J. Transitions to sustainable development. In New Directions in the Study of Long TermTansformative Change; Routledge: New York, NY, USA, 2010.

6. Verbong, G.; Loorbach, D. Governing the Energy Transition: Reality, Illusion or Necessity; Routledge: London, UK, 2012.

7. Rotmans, J.; Kemp, R.; Van Asselt, M. More evolution than revolution: Transition management in public policy. Foresight 2001, 3, 15-31. [CrossRef]

8. Loorbach, D. Transition Management: New Mode of Governance for Sustainable Development. Ph.D. Thesis, Erasmus University Rotterdam, Rotterdam, The Netherlands, 2007.

9. Loorbach, D. Transition management for sustainable development: A prescriptive, complexity-based governance framework. Governance 2010, 23, 161-183. [CrossRef]

10. TNO. Het Fossiele Dilemma van Rotterdam. 2016. Available online: https://hcss.nl/sites/default/files / files/reports/het_fossiele_dilemma_van_rotterdam-tno_paper_maart_2016.pdf (accessed on 5 May 2016).

11. Loorbach, D.; Frantzeskaki, N.; Avelino, F. Sustainability transitions research: Transforming science and practice for societal change. Ann. Rev. Environ. Resour. 2017, 42, 599-626. [CrossRef]

12. Geels, F.W. Technological transitions as evolutionary reconfiguration processes: A multi-level perspective and a case-study. Res. Policy 2002, 31, 1257-1274. [CrossRef]

13. Geels, F.W. From sectoral systems of innovation to socio-technical systems: Insights about dynamics and change from sociology and institutional theory. Res. Policy 2004, 33, 897-920. [CrossRef]

14. Geels, F.W. Regime resistance against low-carbon transitions: Introducing politics and power into the multi-level perspective. Theory Cult. Soc. 2014, 31, 21-44. [CrossRef] 
15. Smith, A.; Voß, J.P.; Grin, J. Innovation studies and sustainability transitions: The allure of the multi-level perspective and its challenges. Res. Policy 2010, 39, 435-448. [CrossRef]

16. De Haan, H. Towards Transition Theory. Ph.D. Thesis, Erasmus University Rotterdam, Rotterdam, The Netherlands, 2010.

17. Rotmans, J.; Loorbach, D. Towards a better understanding of transitions and their governance. A systemic and reflexive approach. In Transitions to Sustainable Development-New Directions in the Study of Long Term Transformation Change; Routledge: New York, NY, USA, 2010; pp. 105-220.

18. Van Raak, R. Transition Policies; Connecting system Dynamics, Governance and Instruments in an Application to Dutch Healthcare. Ph.D. Thesis, Erasmus University Rotterdam, Rotterdam, The Netherlands, 2016.

19. Arranz, A.M. Lessons from the past for sustainability transitions? A meta-analysis of socio-technical studies. Glob. Environ. Chang. 2017, 44, 125-143. [CrossRef]

20. Turnheim, B.; Geels, F.W. Regime destabilisation as the flipside of energy transitions: Lessons from the history of theBritish coal industry (1913-1997). Energy Policy 2012, 50, 35-49. [CrossRef]

21. Turnheim, B.; Geels, F.W. The destabilisation of existing regimes: Confronting a multi-dimensional framework with a case study of the British coal industry (1913-1967). Res. Policy 2013, 42, 1749-1767. [CrossRef]

22. Karltorp, K.; Sandén, B.A. Explaining regime destabilisation in the pulp and paper industry. Environ. Innov. Soc. Transit. 2012, 2, 66-81. [CrossRef]

23. Bosman, R.; Loorbach, D.; Frantzeskaki, N.; Pistorius, T. Discursive regime dynamics in the Dutch energy transition. Environ. Innov. Soc. Transit. 2014, 13, 45-59. [CrossRef]

24. Bosman, R.; Loorbach, D.; Beers, P.J. Discursive destabilization: A Longitudinal Analysis of Energy Transition Discourse in the Netherlands. Energy Policy. in press.

25. Kivimaa, P.; Kern, F. Creative destruction or mere niche support? Innovation policy mixes for sustainability transitions. Res. Policy 2016, 45, 205-217. [CrossRef]

26. Oxenaar, S.; Bosman, R. The Challenges of Phasing-Out Fossil Fuels in a Fossil Fuel Intensive Economy: The Case of The Netherlands; Elsevier: Aalborg, Denmark, in press.

27. Farla, J.; Markard, J.; Raven, R.; Coenen, L. Sustainability transitions in the making: A closer look at actors, strategies and resources. Technol. Forecast. Soc. Chang. 2012, 79, 991-998. [CrossRef]

28. Meadowcroft, J. What about the politics? Sustainable development, transition management, and long term energy transitions. Policy Sci. 2009, 42, 323. [CrossRef]

29. Avelino, F.; Rotmans, J. Power in transition: An interdisciplinary framework to study power in relation to structural change. Eur. J. Soc. Theory 2009, 12, 543-569. [CrossRef]

30. Avelino, F.; Wittmayer, J.M. Shifting power relations in sustainability transitions: A multi-actor perspective. J. Environ. Policy Plan. 2016, 18, 628-649. [CrossRef]

31. De Haan, F.J.; Rotmans, J. A proposed theoretical framework for actors in transformative change. Technol. Forecast. Soc. Chang. 2018, 128, 275-286. [CrossRef]

32. Smink, M.M.; Hekkert, M.P.; Negro, S.O. Keeping sustainable innovation on a leash? Exploring incumbents' institutional strategies. Bus. Strategy Environ. 2015, 24, 86-101. [CrossRef]

33. Van der Vleuten, E.; Högselius, P. Resisting change? The transnational dynamics of european energy regimes. In Governing the Energy Transition: Reality, Illusion or Necessity; Verbong, G., Loorbach, D., Eds.; Routledge: London, UK, 2012; p. 75.

34. Hengelaar, G.A. The Proactive Incumbent: Holy Grail or Hidden Gem?: Investigating Whether the Dutch Electricity Sector Can Overcome the Incumbent's Curse and Lead The Sustainability Transition (No. EPS-2016-ERIM Series 438-ORG); ERIM Ph.D. Series Research in Management; Erasmus University Rotterdam: Rotterdam, The Netherlands, 2017; Available online: http:/ /hdl.handle.net/1765/102953 (accessed on 5 January 2018).

35. Hengelaar, G.A.; Bosman, R. Wrestling with words: How incumbents shape energy transition debates and policy with reactive and proactive discourses. In The Proactive Incumbent: Holy Grail or Hidden Gem?: Investigating Whether the Dutch Electricity Sector Can Overcome the Incumbent's Curse and Lead the Sustainability Transition (No. EPS-2016-ERIM Series 438-ORG); ERIM Ph.D. Series Research in Management; Erasmus University Rotterdam: Rotterdam, The Netherlands, 2017; Available online: http:/ /hdl.handle.net/1765/ 102953 (accessed on 5 January 2018).

36. Loorbach, D.; Rotmans, J. The practice of transition management: Examples and lessons from four distinct cases. Futures 2010, 42, 237-246. [CrossRef] 
37. Roorda, C.; Wittmayer, J.; Henneman, P.; van Steenbergen, F.; Frantzeskaki, N.; Loorbach, D. Transition Management in the Urban Context-Guidance Manual; Dutch Research Institute for Transitions (DRIFT), Erasmus University Rotterdam: Rotterdam, The Netherlands, 2014.

38. Frantzeskaki, N.; Hölscher, K.; Wittmayer, J.M.; Avelino, F.; Bach, M. Transition Management in and for Cities: Introducing a New Governance Approach to Address Urban Challenges. In Co-Creating Sustainable Urban Futures-A Primer on Transition Management in Cities; Frantzeskaki, N., Hölscher, K., Bach, M., Avelino, F., Eds.; Springer: Basel, Switzerland, 2018.

39. Avelino, F. Power in Sustainability Transitions: Analysing power and (dis) empowerment in transformative change towards sustainability. Environ. Policy Gov. 2017, 27, 505-520. [CrossRef]

40. Holmberg, J.; Robèrt, K.H. Backcasting-A framework for strategic planning. Int. J. Sustain. Dev. World Ecol. 2000, 7, 291-308. [CrossRef]

41. Nattrass, B.; Altomare, M. The Natural Step for Business; New Society Publishers: Gabriola, BC, Canada, 1999.

42. Quist, J. Backcasting for a Sustainable Future: The Impact after 10 Years; Eburon Uitgeverij BV: Delft, The Netherlands, 2007.

43. Greenwood, D.J.; Levin, M. Action research, science, and the co-optation of social research. Stud. Cult. Organ. Soc. 1998, 4, 237-261. [CrossRef]

44. Greenwood, D.J.; Levin, M. Introduction to Action Research: Social Research for Social Change; SAGE Publications: Thousand Oaks, CA, USA, 2006.

45. Wittmayer, J.M.; Schäpke, N. Action, research and participation: Roles of researchers in sustainability transitions. Sustain. Sci. 2014, 9, 483-496. [CrossRef]

46. Wittmayer, J. Transition Management, Action Research and Actor Roles: Understanding Local Sustainability Transitions. Ph.D. Thesis, Erasmus University Rotterdam, Rotterdam, The Netherlands, 2016.

47. RTV Rijnmond. Climate Initiative Rotterdam Faalt. 2013. Available online: https://www.rijnmond.nl/ nieuws / 101929/Climate-Initiative-Rotterdam-faalt (accessed on 12 June 2015).

48. Trouw. Rotterdam Gaat Meer in Plaats van Minder $\mathrm{CO}_{2}$ Uitstoten. 2013. Available online: https:/ /www.trouw. $\mathrm{nl}$ /groen/rotterdam-gaat-meer-in-plaats-van-minder-co2-uitstoten a8631999/ (accessed on 13 June 2015).

49. D’Haese, N. De Transitie Naar een Bio-Economie in Nederland en Vlaanderen Vanuit Havenregionaal Perspectief. Ph.D. Thesis, Erasmus University Rotterdam, Rotterdam, The Netherlands, 2015.

50. Port of Rotterdam Authority (2018a) Jaarverslag 2017. Available online: https://jaarverslag2017. portofrotterdam.com/download_pdf (accessed on 2 February 2018).

51. Nijdam, M. Leader Firms: The Value of Companies for the Competitiveness of the Rotterdam Seaport Cluster (No. EPS-2010-216-ORG); Erasmus Research Institute of Management (ERIM): Rotterdam, The Netherlands, 2010.

52. Meijknecht, J.; Correljé, A.F.; Van Holk, B. A Cinderella Story?: Restructuring of the European Refining Sector; Clingendael International Energy Programme: The Hague, The Netherlands, 2012.

53. Vereniging Nederlandse Chemische Industrie (VNCI). The Chemical Industry in The Netherlands: World Leading Today and in 2030-2050. 2012. Available online: https:/ / www.vnci.nl/Content/Files/file/Toekomst\% 20van\%20de\%20chemie\%20in\%20Nederland/VNCI_visie_2030-2050.pdf (accessed on 5 May 2016).

54. Vereniging Nederlandse Chemische Industrie (VNCI). The Shale Gas Revolution and its Impact on the Chemical Industry in The Netherlands. 2013. Available online: https://www.vnci.nl/Content/ Files / file/Toekomst\%20van\%20de\%20chemie\%20in\%20Nederland/Rapport_VNCI_Deloitte_Schaliegas_ 31October2013.pdf (accessed on 12 May 2015).

55. Port of Rotterdam Authority. Port of Rotterdam Aims to Take the Lead in the Energy Transition. 2016. Available online: https:/ / www.portofrotterdam.com/en/news-and-press-releases/port-of-rotterdam-aimsto-take-the-lead-in-the-energy-transition (accessed on 5 February 2018).

56. RCI. RCI Actieplan Energie: Rotterdamse Uitwerking van het Nationale Energieakkoord voor Duurzame groei. 2013. Available online: http:/ / www.rotterdam.nl/Clusters/Stadsontwikkeling/Document\%202013/ 010Duurzaam/20131212\%20RCI\%20Actieplan\%20Energie-Akkoord\%20-\%20DEF.pdf (accessed on 14 May 2015).

57. United Nations (UN). UN Comtrade Database. 2015. Available online: http:/ / comtrade.un.org/ (accessed on 20 April 2015).

58. Port of Rotterdam Authority. Facts \& Figures: Rotterdam Energy Port and Petrochemical Cluster. 2010. Available online: http:/ / www.portofrotterdam.com/nl/Brochures/Facts-Figures-Rotterdam-Energy-Portand-Petrochemical-Cluster-Eng.pdf (accessed on 17 March 2015). 
59. Port of Rotterdam Authority. Energy Port. 2012. Available online: http://www.portofrotterdam.com/en/ Brochures/Rotterdam-Energy-Port.pdf (accessed on 14 May 2015).

60. Hill, N.; Kollamthodi, S.; Varma, A.; Cesbron, S.; Wells, P.; Slater, S.; Cluzel, C.; Summerton, P.; Pollitt, H.; Billington, S.; et al. Fuelling Europe's Future: How Auto-Innovation Leads to EU jobs. 2013. Available online: http:/ / www.eurobat.org/sites / default/files/51cfcb6d4d573d59c7852a06e9782d1f.pdf (accessed on 2 December 2015).

61. Port of Rotterdam Authority. About the Port Authority. 2018. Available online: https://www.portofrotterdam. com/en/port-authority/about-the-port-authority (accessed on 14 March 2018).

62. Financieele Dagblad (FD). Rotterdamse Haven wil Geld in Bedrijven Stoppen Voor Versnelling Energie-Omslag. 2016. Available online: https://fd.nl/ondernemen/1178264/rotterdamse-haven-wilgeld-in-bedrijven-stoppen-voor-versnelling-energie-omslag\# (accessed on 12 December 2016).

63. Rijksoverheid. Nationale Klimaattop. 2016. Available online: https://www.rijksoverheid.nl/actueel/ nieuws / 2016/10/26/nationale-klimaattop-2016-leidt-tot-grote-co2-reductie (accessed on 30 October 2017).

64. NRC Handelsblad. Wie Niet Mee Wil Doen Moet weg uit de Rotterdamse Haven. 2017. Available online: https:/ / www.nrc.nl/nieuws/2017/03/22/wie-niet-mee-wil-doen-moet-weg-uit-de-haven-7514920-a1551461 (accessed on 30 March 2017).

65. Financieele Dagblad (FD). Rotterdamse Havenondernemers Bijten Terug in Discussie over Vergroening. 2018. Available online: https:/ / fd.nl/economie-politiek/1236626/rotterdamse-havenondernemers-bijtenterug-in-discussie-over-vergroening\# (accessed on 23 April 2018).

66. Rotmans, J.; Bosman, R.; Loorbach, D.; van Raak, R. Transitie-Agenda Biobased Haven Rotterdam. 2017. Available online: https:/ / drift.eur.nl/wp-content/uploads/2018/02/Transitie-agenda-Biobased-HavenRotterdam.pdf (accessed on 24 February 2018).

67. Joosten, T. Blijft Rotterdam tot Minimaal 2043 een Steenkoolhaven? 2017. Available online: https:/ /www.ftm. $\mathrm{nl} /$ artikelen/blijft-rotterdam-tot-minimaal-2043-een-steenkoolhaven?share=1 (accessed on 20 October 2017).

68. Van Raak R Bosman, R.; Rotmans, J. Transitie-Arena Havenbedrijf Rotterdam: Naar een Diverse, Flexibele en Veerkrachtige Haven; Commissioned by Port of Rotterdam Authority Rotterdam; DRIFT: Rotterdam, The Netherlands, 2016.

(C) 2018 by the authors. Licensee MDPI, Basel, Switzerland. This article is an open access article distributed under the terms and conditions of the Creative Commons Attribution (CC BY) license (http:/ / creativecommons.org/licenses/by/4.0/). 